\title{
Addressing Social Loafing on Faculty Committees
}

\author{
Andrea A. Curcio and Mary A. Lynch \\ "Do all committee work enthusiastically but incompetently; that way your colleagues will say, 'She \\ is really great, but please don't put her on my committee!"
}

-Half-joking advice given to one of us as we entered the academy.

\section{Introduction}

Law faculty self-governance occurs largely through faculty committees, and that self-governance plays an integral role in academic freedom. ${ }^{\mathrm{I}}$ While most law faculty members vigorously defend their right to academic freedom and self-governance, for some that defense fails to translate into a willingness to fully engage in the committee work necessary to ensure meaningful selfgovernance. This is problematic on two fronts. First, by withdrawing from governance activities, we participate in the demise of academic freedomfreedom sustained by faculty activism, agreement and disagreement over institutional policies, initiative, and directions. ${ }^{2}$ Second, the failure of some

Professor Andrea A. [Andi] Curcio is a Full Professor at Georgia State University College of Law. Mary A. Lynch is a Professor of Law at Albany Law School. The co-authors have twentythree (Curcio) and twenty-seven (Lynch) years of experience in the academy, have taught across the curriculum and have each served as chairwomen or members of numerous committees at their respective institutions. In addition, they have served in leadership positions in national legal education associations providing them with a landscape view of legal education. The authors thank professors Lisa Bliss and Christian Sundquist, Interim Dean Wendy Hensel and Dean Alicia Oullette for their very helpful comments on an earlier draft. They also thank Professor Robert Keuhn, Mary Armistead and the law librarians at their respective institutions for their able research support.

I. See On the Relationship of Faculty Governance to Academic Freedom, in Am. Ass'n of Univ. Professors, Policy Documents and Reports i23 (irth ed. 20I5) (discussing how and why faculty governance is critical to the maintenance of principles of academic freedom).

2. Mary Burgan, Careers in Academe: Women in the "Pre-Feminist" Generation in the Academy, in Over Ten Million Served: Gendered Service in Language and Literature Workplaces 3I (Michelle A. Massé \& Katie J. Hogan eds., 20io) [hereinafter Over Ten Million Served] (noting that academic freedom requires active debate about institutional policy issues and initiatives).

Journal of Legal Education, Volume 67, Number I (Autumn 2017) 
to do their fair share of committee work creates workload equity and social responsibility problems. ${ }^{3}$

Because faculty self-governance is integral to the effective functioning of law schools, and because that self-governance requires productive committees, the "reward" for efficient and strong faculty service work performance is often more service work. ${ }^{4}$ The opposite is also true. Faculty members who demonstrate lack of competence or responsibility when engaging in committee work are not called upon to serve. How this plays out in our experience, and that of our colleagues at other law schools, is that some faculty members do significantly more than others when it comes to the labor necessary to sustain and build their institutions.

The tendency of some to sit back and let others do the work when working in groups such as committees has a name: "social loafing." Often called the "free-rider" problem, ${ }^{5}$ social loafing can lead to inequitable workloads, and, according to social cognition theorists, unchecked social loafing can have a spillover effect on those who do carry their fair share of the workload, as well as on those who traditionally pick up the slack for the loafers. ${ }^{6}$

We suspect that social loafing is a well-recognized, if unnamed, phenomenon at many law schools. This phenomenon is particularly vexing because it has tangible career consequences. While the institution benefits from both committee workers and productive scholars, financial, institutional, and career rewards rest largely on scholarly productivity. Socially responsible faculty members who fully engage in committee work help sustain a robust system of faculty governance. However, they do so at the expense of time available for their own scholarly pursuits. By ensuring the work gets done, they also provide some colleagues the freedom to disengage and focus on individual careerenhancing scholarly endeavors with no penalty and potentially significant individual rewards. This can create significant institutional inequities. The

3. See Amir Erez et al., Effects of Rotated Leadership and Peer Evaluation on the Functioning and Effectiveness of Self-Managed Teams: A Quasi-Experiment, 55 Personnel Psychol. 929, 93I (2002) (noting that "doing a fair share of the team's work maintains equity norms, social responsibility norms, and norms of reciprocity"). See also Cassandra M. Guarino \& Victor M.H. Borden, Faculty Service Loads and Gender: Are Women Taking Care of the Academic Family?, Res. Higher Educ. (forthcoming) (finding that female faculty perform significantly more internal service than their male counterparts and noting that this finding raises equity issues in terms of salary differentials and overall success in academia).

4. Nancy B. Rappaport, "Venn" and the Art of Shared Governance, 35 U. Tol. L. Rev. I69, I79 n.43 (2003). See also Phyllis van Slyck, Welcome to the Land of Super-Service, A Survivor's Guide ... and Some Questions, in Over Ten Million Served, supra note 2, at 195, 202 (noting that faculty who perform extraordinary service without complaint are often "rewarded" by being given additional administrative work).

5. The terms free-riding and social loafing are both used to describe situations in which one or more group members fails to do their fair share of the work. Barbara Maiden \& Bob Perry, Dealing with Free-Riders in Assessed Group Work: Results from a Study at a UK University, 36 AssessmenT \& Evaluation Higher Educ. 45I, $45^{2}$ (20ii).

6. See infra text and accompanying notes $36-39$ (discussing social loafing studies). 
question is what to do about it. That question is all the more pressing given ongoing changes to the existing legal education model that require significant faculty input and committee work in an era when many schools have seen a reduction in full-time faculty available to do that work.7

In this article, we suggest that rather than conceding important decisionmaking to administrators or perpetuating a potentially unsustainable model of disparate service workload allocations, law schools need to explore ways to equitably allocate and encourage institutional service work. ${ }^{8}$ This is especially important because sustained workload inequities, along with a system that neither rewards extraordinary work nor penalizes substandard work, can induce what is known as "the sucker effect." In other words, it can lead those who have traditionally carried the lion's share of the work to reduce the injustice of the situation by reducing their own level of effort. ${ }^{9}$

One way to address the problem of inequitable committee workload contributions is to learn from the social cognition literature on social loafing. That literature addresses the causes of, and solutions to, inequitable group work contributions. Studies suggest that making group members' contributions visible and evaluable, via small committee size and committee work evaluations, reduces social loafing. ${ }^{\text {.0 }}$ This article discusses both of those ideas and particularly looks at using committee work contribution evaluations to highlight communal responsibilities, set clear expectations, communicate that certain behaviors are valued and important, and motivate change by setting normative standards for committee work participation. ${ }^{\mathrm{II}}$ It also suggests another way to address workload inequities: rewarding committee workhorses with release time from committee work.

7. See infra Part I. See also Andi Curcio, The PotentialAdjunctification of Law School Faculties. A PLAce to discuss Best Practicies for Legal Education (May i7, 20I7) https://bestpracticeslegaled. albanylawblogs.org/2017/05/r7/the-potential-adjunctification-of-law-school-faculties/ [https://perma.cc/E $\left.{ }_{2} \mathrm{KK}-\mathrm{MW} 84\right]$.

8. Service work extends far beyond work on faculty committees. In this article, we focus mainly on solutions to dilemmas created by the current distribution of faculty committee work. However, we believe that the big-picture issues of what counts as service and how that work should be evaluated and credited deserves serious study. For a discussion of various types of service and a general framework for evaluating service contributions, see Jeanette Clausen, Rewarding Work: Integrating Service into an Institutional Framework on Faculty Roles and Rewards, in Over Ten Million Served, supra note 2, at 23I, 238-39. In this piece, we focus exclusively on inequities resulting from faculty committee service workloads. We recognize other inequities, such as teaching load and status, also exist and should be addressed. A discussion of those inequities is beyond the scope of this essay.

9. Mel E. Schnake, Equity in Effort: The "Sucker Effect" in Co-Acting Groups, I7 J. MGmT. 4I, 42 (I99I) (describing studies of the "sucker effect," i.e., the phenomenon in which an individual refuses to be played for a "sucker" and thus withholds effort when he or she believes other capable groups members are consciously withholding effort).

IO. For a discussion of these studies, see infra Part IIB.

II. Peter G. Dominick et al., The Effects of Peer Feedback on Team Member Behavior, 22 Group \& Org. MGMT 508, 514-I5 (I997) (noting that peer evaluations of group work contributions serve these purposes). 
Part I discusses changes in legal education that likely will result in the need for more committee work as well as fewer full-time faculty available to do the work. It suggests that these changes will require a shift in the current laissezfaire approach taken with those faculty members who choose not to participate fully in committee work. Part II reviews the social cognition theory literature and, based on that literature, proposes two potential ways to mitigate social loafing on faculty committees: smaller committees and evaluation of committee work contributions. To help faculties envision what an evaluative instrument might look like, we provide a sample rubric in Appendix A. Part III suggests rewards for extraordinary committee work, including committee release time. It suggests that service work release time does not affect budgets and helps level the playing field, ensuring those who provide extraordinary institutional service also have time to engage more fully in the scholarly endeavors that typically result in financial and reputational rewards. In conclusion, the article notes that the legal academy is at a critical juncture that necessitates examining alternatives to the current committee workload allocation model to preserve our system of faculty governance and allow our institutions to thrive.

\section{Addressing Faculty Members' Committee Work Performance: Why Now?}

Faculty participation in the direction of the law school is among the privileges, duties, and rights associated with academic freedom and faculty governance. ${ }^{12}$ Faculty members play critical roles in defining and implementing institutional missions, strategic planning, curriculum, and numerous other decisions that affect the school's direction and educational focus. Most of this work is done via committees and task forces.

As legal education models change, most schools are experiencing an increase in faculty committee work responsibilities. Market forces are putting pressure on law schools to design, revise, innovate, create, and assess learning and to focus on the competencies students need to be successful in a changing legal services industry. Additionally, declining enrollment ${ }^{13}$ and the restructuring of

I2. Faculty governance is written into the ABA and AALS accreditation standards. See, e.g., Section of Legal Educ. and Admissions to the Bar, Am. Bar. Ass'n, ABA Standards and Rules of Procedure for Approval of Law Schools, 20I6-20I7 Standards 20I(a), at 9; 315, at 23; 404(a), at 28 (20I6) [hereinafter ABA Standards]; Ass'n of Am. Law Schs, 2016 AALS HandBook Bylaws, $\$ 6.4$ (c), 6.5 (a), at 57-58 (2016).

13. Mary Lynch, Plummeting Admissions Numbers Decrease Cost of Clinical Courses Relative to Other Courses, Best Practices for Legal Educ. (Feb. 22, 20I3), http://bestpracticeslegaled. albanylawblogs.org/2013/o2/22/plummeting-admissions-numbers-decrease-cost-of-clinicalcourses-relative-to-other-courses/ [https://perma.cc/JJ7 $\mathrm{F}^{\left.-\mathrm{NSN}_{3}\right]}$. First year law school enrollment rapidly decreased starting in the 20II-I2 through the 20I2-20I3 academic years. See Section of Legal Educ. and Admissions to the Bar, Am. Bar. Ass'n, Enrollment and Degrees Awarded ig63 TO 20I2, ACAdEMic Years, https://www.americanbar.org/content/ dam/aba/administrative/legal_education_and_admissions_to_the_bar/statistics/ enrollment_degrees_awarded.authcheckdam.pdf [https://perma.cc/88J9-N6QN] (last visited May 26, 2017) Reports from 20I4 through 20I5 continued to show sharp decreases in iL enrollment with a flattening out in 20i6. See Section of Legal Educ. and Admissions to 
the global market for lawyer/legal services ${ }^{14}$ have led law schools to explore additional revenue sources and new ways to serve the public, including LL.M. programs, post-J.D. certificates, a one-year master's program, two-year accelerated J.D., online classes and programs, and various other examples of outreach and innovations. As law schools develop and market new opportunities, faculty governance imperatives require faculty involvement, resulting in rapidly expanding faculty committee responsibilities.

When law schools innovate, reorganize, and evolve, faculty have two choices: continue a model of self-governance in which the faculty remains heavily involved in influencing, implementing, and assessing adaptations to their schools' educational programming model, or cede these decisions to law school and university administrators. Even if faculties choose the latter course, accreditation standards still require significant faculty involvement in many institutional decisions. ${ }^{5}$

For example, recently revised American Bar Association accreditation Standard 315 requires that the dean and the faculty "conduct ongoing evaluation of the law school's program of legal education, learning outcomes, and assessment methods" ${ }^{16}$ and "use the results of this evaluation to determine the degree of student attainment of competency in the learning outcomes and to make appropriate changes to improve the curriculum." ${ }^{77}$ The new accreditation standards create increased expectation for collective faculty committee service in areas in which the faculty as a whole are not currently expert. Moreover, faculty, via committees, will need to work with the administration to create and implement assessment systems for retrieving the necessary data and

the Bar, Am. Bar. Ass'n, Statistics, Change in iL Matriculants by School-20I5 vs 2014 (at https://www.americanbar.org/groups/legal_education/resources/statistics.html look under Longitudinal and Historical Data heading and download Excel database entitled Comparison of 2015 and 2014 IL Matriculants (20I5_2OI4_Il_matriculatn_comparison. authcheckdam.xlsx)) and Section of Legal Educ. and Admissions to the Bar, Am. Bar. Ass'n, Statistics, 2015 v. 2016 Change in iL Enrollment (at https://www.americanbar. org/groups/legal_education/resources/statistics.html look under Current Year heading and download Excel database entitled 20I5 v. 2016 Change in IL Enrollment (20I6_v_2OI5_Il_ matriculatns_authcheckdam.xlsx)) (last visited May 26, 2017). Fewer first-year students enrolled in ABA-accredited schools in 20I5 and 2016 than at any time before r974. Moreover, no one anticipates returning to the admissions landscape of the rg9os and early 2000 .

I4. William D. Henderson, A Blueprint for Change, 4o PEPP. L. Rev. 46I, 479-9o (2013) (discussing changing global market for lawyers and the impact on legal education). Professor Richard Susskind has also written about the changing nature of legal markets. See, e.g., Richard Susskind, The End of Lawyers?: Rethinking the Nature of Legal Services 6, 9-iI, 28-33 (20IO). See generally Richard Susskind, Tomorrow's Lawyers: An Introduction to Your Future (20I3): William D. Henderson \& Rachel M. Zahorsky, Paradigm Shift, A.B.A. J., July 2OII, at 40 .

I5. See, e.g., ABA Standards, supra note I2, Standards 20i(a), at 9; 315; at 23; 404(a), at 28.

I6. Id. at Standard $3{ }^{1} 5$, at 23 .

I7. Id. 
information to comply with the revised standards, without impinging on academic freedom..$^{18}$

The likely increase in committee service work is occurring at a time of shrinking full-time tenure or tenure-equivalent faculty hires, i.e., in the faculty who possess the privileges, duties, and rights of faculty governance. ${ }^{19}$ All of higher education is experiencing shrinkage of tenure-track faculty, ${ }^{20}$ and law schools are not immune to this phenomenon. ${ }^{21}$ Law schools are taking a hard look at faculty numbers and costs as they attempt to manage their budget challenges in an era of declining admissions and escalating demands. ${ }^{22}$ Some reductions in faculty have happened more quietly than others. ${ }^{23}$ However, current trends suggest that nationwide, and certainly in many individual schools, there will be fewer full-time faculty ${ }^{24}$ and more institutional work for those faculty members.

I8. See Mary A. Lynch, An Evaluation of Ten Concerns About Using Outcomes in Legal Education, 38 WM. Mitchell L. Rev. 976, 990 (20I2) (noting faculty concerns that outcome measures will lead to loss of academic freedom by dictating what should be taught and how it should be evaluated).

I9. Faculty governance responsibilities vary among schools, but at all schools, full-time doctrinal and clinical faculty have the rights, privileges, and responsibilities of faculty governance. ABA Standards, supra note I2, Standard 405 (c), at 29; Interpretation 405-8, at 30 ("A law school shall afford to full-time clinical faculty members participation in faculty meetings, committees and other aspects of law school governance in a manner reasonably similar to other full-time faculty members.").

20. For a discussion of the decline in tenure-track faculty generally, see Katie J. Hogan, Superserviceable Feminism, in Over Ten Million Served, supra note 2, at 55, 57; Katie J. Hogan \& Michelle A. Massé, Introduction, in Over Ten Million Served, supra note 2, at I.

21. Paul Caron, Law Schools Have Shed I,46o Full-Time Faculty (I6.I\%) Since 2oro, TAxProf Blog (Jan. I7, 2017), http://taxprof.typepad.com/taxprof_blog/20I7/oI/law-schools-have-shed-I46ofull-time-faculty-I6I-since-2OIo.html [https://perma.cc/4 $\left.\mathrm{UN}_{3}-\mathrm{YDB}_{2}\right]$ (noting that data compiled by Matt Leichter from ABA-required reports indicates i6.1\% fewer full-time law faculty members in 2016 than in 2010 , with 149 schools reporting reductions and twenty schools reporting losing more than twenty faculty members).

22. Paul Caron, Deans Respond to TaxProf Blog Posts on Faculty Layofs, TaxProf Blog (Mar. 26, 20I4), http://taxprof.typepad.com/taxprof_blog/2OI4/o3/deans-respond.html [https:// perma.cc/BN95-9AF2] (quoting then-AALS president Dan Rodriguez "[t]hat law schools are looking to manage their costs by taking close looks at their faculty labor force seems entirely sensible.").

23. Debra Cassens Weiss, Law Schools Cope with Declining Enrollment by Quietly Cutting Faculty, ABA J. (July i6, 2013, I2:02 PM), http://www.abajournal.com/news/article/law_schools_ cope_with_declining_enrollment_by_quietly_cutting_faculty/[https://perma.cc/ R2RC-DCGX].

24. Matt Leichter, Which Law Schools Are Shedding Full-Time Faculty? (20I4 Edition), The Last Gen X Aм. (Dec. I8, 20I4), https://lawschooltuitionbubble.wordpress.com/20I4/ı2/18/which-lawschools-are-shedding-full-time-faculty-20I4-edition/ [https://perma.cc/FRV9-9P92] ("Since last year, the number of fall full-time instructors at all law schools fell by 8 percent; the cumulative decline since 20 Io has been ir percent, so much of what's going on happened just before this academic year."); Debra Cassens Weiss, Law School Faculty Numbers Shrink II Percent Since 2010; Which Schools Shed the Most Full-Timers?, ABA J. (Dec. 22, 2014, 6:15 AM), http:// 
This new reality suggests that continued reliance on the same subset of faculty to perform institutional service, and the laissez-faire approach toward those who do not fully participate, may be an unsustainable model. There will simply be too much work and too few people to perform that work. Moreover, those who have been willing to step up in the past, if now overburdened by even more unrewarded work and with even less time for scholarly endeavors, may rationally decide to withdraw from participating in a system that penalizes them for their institutional citizenship. ${ }^{25}$ Thus, we suggest that to maintain a viable system of faculty governance, and to survive and thrive, law schools must find ways to more equitably distribute service workloads.

\section{Confronting Committee Workload Disparities}

\section{A. Institutional Structures that Foster Committee Workload Disparities}

Full-time faculty jobs require engagement in scholarship, teaching, and service. While service is a communal undertaking, scholarship and teaching have traditionally been solitary activities resulting in individual achievements. ${ }^{26}$ Promotions, institutional rewards, and faculty members' external reputations are largely based upon individual achievements, and particularly scholarly productivity rather than community engagement and service to the collective endeavor. ${ }^{27}$ Thus, for some, there is little incentive to participate in institutionsustaining committee work. As long as colleagues do that work, the institution functions, and the individual faculty member can focus on work that reaps the most tangible rewards-i.e., scholarship.

A rational faculty member, concerned with his or her own advancement, may choose to underperform on service work knowing that such underperformance

www.abajournal.com/news/article/law_school_faculty_numbers_shrink_II_percent_ since_20IO_which_schools_shed/?utm_source=maestro\&utm_medium=email\&utm_ campaign=daily_email [https://perma.cc/AK96-RYXP] ("Cooley currently has 49 faculty members, compared to Ior faculty members in 20I0. Next on the list are George Washington, which has 34 fewer full-time faculty members in four years; Florida Coastal, which lost 33; Vermont, which lost 29; and Pacific McGeorge, which lost 27. Two law schools now have only eight full-time instructors. They are La Verne and Appalachian, whose faculties shrunk by 50 percent or more since 2010."); Paul Campos, Law School Fires (or Otherwise Terminates with Extreme Prejudice) Nearly 60\% of Its Faculty, Law., Guns \& Money (Dec. I3, 20I4), http://www. lawyersgunsmoneyblog.com/2014/12/nations-largest-law-school-fires-otherwise-terminatesextreme-prejudice-nearly-6o-faculty [https://perma.cc/ZM $\left.37-\mathrm{TV}_{3} 6\right]$.

25. See Norbert L. Kerr, Motivation Losses in Small Groups: A Social Dilemma Analysis, 45 J. Personality \& Soc. Psychol. 8Ig (I983) (discussing how some group members, refusing to be "suckers," reduced their efforts when others capable of contributing to the group did not do so); see also Schnake, supra note 9 (describing the "sucker effect").

26. Michael I. Meyerson, Law School Culture and the Lost Art of Collaboration: Why Don't Law Professors Play Well with Others?, 93 NeB. L. Rev. 547, 563 (2014) ("For most, though certainly not all, law professors, both teaching and scholarship are seen as solitary activities."); see also, Donald E. Hull, The Hermeneutics of Service, in Over Ten Million SERved, supra note 2, at 219, 220

27. Id . 
is both likely to result in fewer or less work-intensive committee assignments ${ }^{28}$ and that less committee work means more time to engage in career-enhancing work, or just more time to spend with friends and family. A rational dean may choose a managerial strategy in which the same worker bees ${ }^{29}$ are asked to perform the institutional labor because that strategy ensures the work will be done.

One oft-heard comment is that the reason for the difference in institutional workload allocation is that different people have different strengths: Some excel at scholarship, while others excel at teaching, and others perform exceptional service. The common wisdom is that a smart dean plays to his or her faculty members' strengths. $3^{\circ}$ For many deans, this means assigning light committee workloads to prolific scholars, avoiding assigning important committee work to those who do it poorly or resist strongly, and assigning the heavy-lifting committee work to those who get that work done.

While prolific scholarship, great teaching, ${ }^{3^{1}}$ and institutional service all benefit the institution, the model for distributing committee workloads has real-world consequences for individual faculty members. Time to engage in scholarship, and hence greater scholarly productivity, often results in a wide range of internal and external rewards: course releases, merit raises, national reputations, and additional job prospects..$^{32}$ Those with significant committee work responsibilities must either forgo time that otherwise would be spent on scholarship or work longer hours to achieve the same scholarly productivity levels as those colleagues with significantly less committee work. For example, one study found that although both male and female undergraduate associate professors averaged a sixty-four-hour work week, institutional service work and other institutional commitments resulted in the women professors having 220 fewer hours than their male counterparts to devote to scholarly endeavors during the academic year. 33 That time differential can profoundly affect scholarly productivity.

28. See Rappaport, supra note 4 , at n.43 (noting that those who underperform on committee work tend not to be asked to do time consuming important institutional labor because of a dean's fear that assigning those people to do the work will result in the work not getting done).

29. Jon H. Sylvester \& Anthony J. Pagano, It's Not fust a fob, It's an Adventure, 34 U. ToL. L. Rev. I65, I73 (2002) (describing those who deans can count on to do more than their fair share of the work without complaint and without keeping tabs as "worker bees").

3o. $\quad I d$. at $\mathrm{I}_{7} 6$.

3. Because we focus expressly on faculty committee service workload, we consider issues concerning appropriate motivation of effective teaching to be beyond the scope of this article.

32. See Ronald H. Silverman, Weak Law Teaching, Adam Smith and a New Model of Merit Pay, g Cornell J. L. \& Pub PoL'y 267, 366-67 (2000) (describing some of the external and internal rewards available to productive scholars and noting that this reward structure often encourages scholarship over teaching).

33. Joya Misra et al., The Ivory Ceiling of Service Work, Academe, Jan-Feb. 20II, at 22, 24 (20II) 
When prolific scholars get course releases or other workload releases as a reward and incentive to continue their scholarly pursuits, the cycle of rewards accompanying scholarly productivity becomes self-perpetuating. Thus, the oft-heard justification for light-loading some faculty members on committee work because they are prolific scholars should be looked at in light of the real-world advantages and disadvantages this produces for individual faculty members and its impact on the institution.

Efforts to equalize workload distribution can provide institutions with valuable data to support or counter assumptions about whether the current model actually best serves the institution. For example, would more equitable committee workloads increase the scholarly productivity of the committee workhorses and thus enhance the institution's overall reputation? If the faculty wants to sustain a meaningful system of self-governance, how many "prolific scholars" who perform little or no institutional service can the institution continue to afford in light of changing demands by consumers, employers, and accreditors? These questions may be best answered by experimenting with changes to the status quo.

The need to explore new ways of committee work accountability may be especially pressing if schools find that many of their current institutional service worker bees are baby boomers. These stalwarts of institutional labor will begin to retire. Studies suggest that younger generations of workers believe work is less central to their lives, and value leisure time and work/ life balance more than their baby boomer counterparts. ${ }^{34}$ These generational differences may play a role in younger faculty members' willingness to engage in unrecognized and unrewarded institutional service contributions, and they may be particularly reluctant to pick up the slack for colleagues who choose not to engage in committee work.

With the likely increase in committee work, reduction in faculty available to do that work, and a new generation of faculty members potentially less willing to compensate for those who choose not to contribute, it is time to explore alternatives to the status quo. We suggest looking to social cognition literature for insights into how to create more equitable workload distributions and ensure a sustainable model of faculty governance in the changing landscape of legal education.

\section{B. Social Loafing: Causes, Consequences, and Remedies}

Committees often consist of members who perform the lion's share of the committee's work and those who do little to contribute to the committee's charged tasks. In this section, we discuss the social cognition theories

(finding female associate undergraduate professors spent approximately 4.5 more hours per week on institutional service than their male counterparts). For a brief discussion of gender and racial inequities in service workload distribution, see infra note $6 \mathrm{~g}$.

34. Jean M. Twenge, A Review of the Empirical Evidence on Generational Differences in Work Attitudes, 25 J. Bus. Psychol. 20I, 204 (20IO) (reviewing numerous empirical studies on generational difference in work attitudes). 
underlying the choice to let one's colleagues carry the committee service workload, the negative consequences that flow from unchecked disparate group work contributions, and the lessons from social cognition theory on how to remedy inequitable service workloads.

Social cognition theorists coined the term "social loafing" to describe a reduction in effort when working on a joint product where one's work cannot be judged separately from the collective product.35 Alternatively, when some believe their co-workers cannot be trusted to perform, they pick up the slack and do more than their fair share, resulting in what social cognition theorists call "social compensation." ${ }^{6}$ Both social loafing and social compensation may cause resentment and frustration among those who believe that they carry more than their fair share of the committee workload. ${ }^{37}$ Perceptions that coworkers are loafing may reduce the performance of other group members, thus resulting in a weaker group performance and product. $3^{3}$ Sustained workload inequities, along with a system that neither rewards extraordinary work nor penalizes substandard work, also may lead those who have traditionally done more than others to reduce the injustice of the situation by reducing their own level of effort to avoid being "suckers." 39

Fortunately, based on studies of student work groups and multiple nonacademic workplaces, ${ }^{40}$ the literature on social loafing offers guidance on

35. Steven J. Karau \& Kipling D. Williams, Social Loafing: A Meta-Analytic Review and Theoretical Integration, 65 J. Personality \& Applied Psychol. 68I, 68I (i993) [hereinafter Karau \& Williams, Meta-Analysis].

36. See Kipling D. Williams \& Steven J. Karau, Social Loafing and Social Compensation: The Effects of Expectations of Co-Worker Performance, 6i J. Personality \& Soc. Psychol. 570, 57I (I991) (discussing social compensation theory).

37. Susan Durham, Janet Merritt \& Jeanne Sorrell, Implementing a New Faculty Workload Formula, 28 Nursing Educ. Persp. I84, I84 (2007) (noting that "perception of workload equity is a significant variable related to faculty job satisfaction").

38. Jasmine Tata, The Influence of Accounts on Perceived Social Loafing in Work Teams, I3 InT'L J. Conflict Mgmt. 292, 293 (2002).

39. For studies discussing the "sucker effect," i.e., the phenomenon in which an individual refuses to allow others to benefit from his or her work and withdraws effort when he or she believes other capable group members consciously choose to withhold their effort, see Schnake, supra note 9; Kerr, supra note 25.

40. We review the literature with the caveat that most social loafing studies in academia have occurred in context of student work groups rather than among adult workers, and virtually no studies exist on the unique aspects of social loafing in context of academic committees. See e.g., Susan M. Murphy et al., Understanding Social Loafing: The Role of Fustice Perceptions and Exchange Relationships, 56 Hum. ReL. 6I, 63 (2003) (noting that "there are only a handful of studies examining social loafing in actual work groups"). Workplace studies include the following: Robert C. Liden et al., Social Loafing: A Field Investigation, 3o J. MGmT. 285 (2004) (looking at various aspects of social loafing in twenty-three work groups totaling i68 people in two different workplaces); Jennifer M. George, Extrinsic and Intrinsic Origins of Perceived Social Loafing in Organizations, 35 ACAD. MGmT. J. I9I (1992) (examining the impact of task visibility and intrinsic value on workplace social loafing). The findings of what motivates group work participation in the workplace largely mirror the findings of what motivates participation in 
how to mitigate the problem. We focus on two particular solutions found in this literature, reducing committee size and evaluating committee service, because these changes can be implemented via concrete action steps. Other solutions to social loafing, such as working on intrinsically meaningful tasks, ${ }^{41}$ feeling that one is making a unique, rather than redundant, contribution, ${ }^{42}$ working with highly respected co-workers, ${ }^{43}$ fulfilling a sense of felt responsibility toward one's co-workers or the organization, ${ }^{44}$ and working with highly cohesive groups ${ }^{45}$ rely more on intrinsic motivation and, while useful to keep in mind when making committee assignments, are more challenging to implement systematically.

\section{Carefully Choose Committee Size}

Virtually all faculty members are appointed to committees. Committee workload disparities often have little to do with committee assignments. Instead, workload inequities arise based upon who actually does the work within the committee, as well as who is asked to take leadership roles, either formally as chair or informally because a person is known to get the work done.

Often, to spread the work and ensure a diversity of opinions, deans appoint relatively large faculty committees..$^{6}$ In doing so, deans may be unwittingly

student work groups. Thus, we believe that despite the differences between student work groups and work groups in institutions outside academia, the studies are salient when it comes to faculty committee workload distribution and performance. We suggest that studies of the effectiveness of the methods discussed here when it comes to faculty committee work would be useful and informative.

4I. Karau \& Williams, Meta-Analysis, supra note 35, at 686.

42. Stephen G. Harkins \& Richard E. Petty, Effects of Task Difficulty and Task Uniqueness on Social Loafing, 43 J. Personality \& Soc. Psychol. I2I4, I227 (I982) (finding that motivation to participate in a group endeavor existed when individuals believed they were making a unique contribution, even if their contribution could not be severed from the group's product). See also Karau \& Williams, Meta-Analysis, supra note 35, at 70I (finding task meaningfulness and uniqueness can affect social loafing tendencies).

43. Karau \& Williams, Meta-Analysis, supra note 35, at 7 or.

44. Hwee Hoon Tan \& Min Li Tan, Organizational Citizenship Behavior and Social Loafing: The Role of Personality, Motives, and Contextual Factors, I42 J. Psychol. 89, 94, IO3 (2008) (discussing findings that a sense of felt responsibility when group members depend on one another's work to complete a project negatively correlates to social loafing).

45. Group cohesiveness has been defined as the level of affinity group members have toward one another, their desire to remain and function as part of the group, and the degree to which members value belonging to the group. Id. at 95. It has been found that group cohesiveness reduces social loafing. See, e.g., Steven J. Karau \& Kipling D. Williams, The Effects of Group Cohesiveness on Social Loafing \& Social Compensation, i Group Dynamics: Theory, Res. \& Prac. I56, I65 (I997).

46. Rena I. Steinzor \& Alan D. Horstein, The Unplanned Obsolescence of American Legal Education, 75 Temp. L. Rev. 447, 476 (2002) (noting that for key committees, deans appoint a wide array of faculty with differing experiences and viewpoints to avoid political fallout from those who feel their voice was not represented on the committee). 
facilitating social loafing. Studies find that the larger the group, the more likely social loafing will occur. ${ }^{47}$ Large groups enable some individuals to hide in the crowd, avoiding the negative consequences of slacking off, and, at the other end of the spectrum, some do not contribute because they get lost in the crowd and do not get credit for the individual effort they expend..$^{8}$ Some feel a lack of accountability because withholding effort allows them to reap the same rewards as those who put in effort. ${ }^{49}$ Others may be unwilling to exert effort if they believe that their effort adds little to the group product-i.e., to the extent their input is dispensable in terms of the final product, their motivation to participate decreases even when their contribution is made identifiable. ${ }^{5 \circ} \mathrm{It}$ has even been suggested that "in some cases individuals may simply not be aware of the effort they are expending when part of a large group, and thus any reduction in effort may be unintentional. ${ }_{5^{\mathrm{I}}}$

One solution to social loafing is to appoint small committees. Small committees can increase feelings of individual accountability and make it easier to identify who is responsible for a positive outcome. Studies of teambased learning suggest ideal work group size ranges from two to seven people, depending upon the project. $5^{2}$ However, no consensus exists about ideal workplace teams because workplace team size often depends on task and work environment. Additionally, concern about social loafing is just one of many considerations when forming work teams, such as faculty committees, because issues such as diversity of opinion, committee members' individual expertise and interest in the project, the scope of the committee's tasks, and other factors play a role in committee composition. Given these realities, if large committees are necessary, it may be useful to divide the work into tasks or projects that can be accomplished by smaller subcommittees.

47. See, e.g., Karau \& Williams, Meta-Analysis, supra note 35, at 697 (discussing studies showing that social loafing is more likely to occur in large groups); Liden et al., supra note 40 , at 289 (citing studies and suggesting reasons that large group size results in greater social loafing); Praveen Aggarwal \& Connie L. O'Brien, Social Loafing on Group Projects: Structural Antecedents and Effect on Student Satisfaction, 30 J. Marketing Educ. 255, 260 (2008) (finding bigger groups "created conditions that were more conducive to social loafing").

48. Bibb Latané et al., Many Hands Make Light the Work: The Causes and Consequences of Social Loafing, 37 J. Personality \& Soc. Psychol. 822, 830 (1979); Karau \& Williams, Meta-Analysis, supra note 35 , at $68_{3}$.

49. Liden et al., supra note 40 , at 289 .

50. Karau \& Williams, Meta-Analysis, supra note 35 , at $68_{3}$.

5. $\quad$ Liden et al., supra note 40 , at 289 .

52. See L. Dee Fink, Beyond Small Groups: Harnessing the Extraordinary Power of Learning Teams, in TeAmBased Learning: A Transformative Use of Small Groups 3, i5 (Larry Michaelsen et al. eds., 2004) (noting that when it comes to cooperative and team-based learning "groups of 8 or more tend to be inefficient and ineffective"); Laura Helle et al., Project-Based Learning in Post-Secondary Education-Theory, Practice and Rubber Sling Shots, 5I Higher Educ. 287, 30 I (2006) (reviewing descriptive and analytical literature and suggesting that for project-based learning, group sizes of two to five generally work well). 


\section{Evaluate Committee Work}

While small committees may help mitigate social loafing, small committees may not always be viable, and even within those committees some faculty members still may end up doing the lion's share of the work given the dynamics of the committee or the nature of the work. Thus, we suggest faculties and deans develop concrete ways to evaluate committee work.

Why evaluate? A concrete evaluative process indicates that committee work matters, and the evaluative process itself sets behavioral norms. Evaluating committee work performance signals a shift from the current laissez-faire attitude toward committee work contributions. As one study noted, evaluation puts behaviors in a team context, focuses attention on behaviors relevant to effective performance, communicates certain behaviors are valued and important, and motivates change by visibly demonstrating discrepancies between behaviors and standards. 53

What would a committee work evaluation look like? The answer to that question is a decision best left to individual faculties. However, to help faculties envision what such an evaluation might encompass, we provide a sample committee work contribution rubric [see Appendix A].

Another significant question is: Who completes the evaluative rubric? Again, this question is best answered according to a particular law school's culture and circumstance. Committee members could self-assess, using a rubric such as that suggested in Appendix A, with committee chair input or review. Alternatively, in institutions where chairs wield persuasion, authority, and gravitas, committee chairs could be asked to complete the evaluation with an opportunity for the committee member to comment. A more radical, potentially more accurate, and admittedly more complex suggestion is that schools use a committee work rubric as the basis for a peer-evaluation model. 54

53. Dominick et al., supra note II, at 515.

54. Peer evaluations are used in other workplaces as part of a 360 -degree review. A 360 -degree review involves multiple evaluators, including supervisor, peer, subordinate, and customer, along with a self-evaluation. Frederick P. Morgeson et al., Coming Full Circle: Using Research and Practice to Address 27 Questions About 36o-Degree Feedback Programs, 57 Consulting Psychol. J. Practice \& Res. ig6, ig6 (2005). Peer evaluations often are an important part of the 36o-degree review process. See, e.g., Maury A. Peiperl, Best Practice, Getting $360^{\circ}$ Feedback Right, HaRv. Bus. Rev., Jan. 20II, at I42, I44 (discussing how to engage employees in effective peer evaluation as part of a 360 -degree review). Studies have found that peer evaluations reduce social loafing. See, e.g., Greg L. Stewart et al., Peer-Based Control in Self-Managing Teams: Linking Rational and Normative Influence with Individual and Group Performance, 97 J. Applied Psychol. 435, 444 (2012) (finding workplace peer evaluations improved both individual and group performance); Charles M. Brooks \& Janice L. Ammons, Free Riding in Group Projects and the Effects of Timing, Frequency, and Specificity of Criteria in Peer Assessments, 78 J. EDuc. FOR Bus. 268, 27I (2003) (finding that peer assessments used for both developmental and evaluative purposes reduced the free-rider problem when the evaluations provided specific feedback and were conducted early in the project and several times during that project); Vanessa Urch Druskat \& Steven B. Wolff, Effects and Timing of Developmental Peer Appraisals in Self-Managing Work Groups, 84 J. Applied Psychol. 58, 7I (I999) (finding peer appraisals can have a positive impact on self-managed work groups); Dominick et al., supra note II, at $5^{\mathrm{I} 2-\mathrm{I} 3}$ (finding that the peer 
Even though the precise content and mechanism of committee work evaluations may be up for debate, it seems clear that assessing faculty contributions is useful. The literature makes clear that using a feedback instrument that contains behavioral items and expectations sends a message that performance should meet the prescribed standards and provides opportunities to learn about, and reflect upon, one's own behaviors in relation to those standards. ${ }^{5}$ Evaluations exert normative controls because of people's desire for belonging, a desire that motivates both compliance with and internalization of group standards. $5^{6} \mathrm{~A}$ rubric such as the one provided in Appendix A sets up clear standards and expectations that individuals who care about their colleagues' good opinion will want to meet. ${ }^{57}$ The evaluations also provide the dean and committee chairs with documented information for dialogue with traditional committee service shirkers-especially if a dean incorporates the evaluations into the formal year-end evaluations. For all these reasons, an evaluative process hopefully deepens the pool of citizens from which to assign work. However, whether the process actually changes the existing culture largely depends upon faculties' willingness to engage in the process and deans' use of information from the evaluations.

As with any change to longtime practice in a culture such as academia, $5^{8}$ schools considering evaluating committee work and thus creating an accountability system for institutional service work must grapple with resistance to change and resistance to accountability structures. They also must address concerns about human behaviors when it comes to both evaluating and being

evaluations improved performance as measured by objective expert ratings). In an academic setting, peer review of committee work contributions raises complex issues such as potential disruption of workplace camaraderie and morale and concerns about the validity of the process because of potential friendship bias or unwillingness to identify noncontributors, especially if those noncontributors will be voting on tenure or promotion. Those concerns would need to be addressed by faculties who seek to engage in peer review evaluations of committee work contributions.

55. Dominick et al., supra note II, at 5I5.

$5^{6 .}$ Stewart et al., supra note 54 , at $43^{6}$.

57. See Brice Corgnet, Peer Evaluations and Team Performance: When Friends Do Worse than Strangers, 50 ECON. InQuiry I7I, I72 (2012) (noting that some studies suggest that "the use of peer evaluations, by focusing the attention of team partners on each other's [sic] contribution, may increase peer pressure and reduce free-riding behaviors in teams."). We speculate that evaluations may also protect junior faculty from senior faculty who tend to "dump" committee work on untenured junior colleagues. An evaluative process may make this kind of conduct more transparent and make it more difficult to turn a blind eye to that kind of behavior.

58. Am. Bar Ass'n Task Force on the Future of Legal Educ., Report and Recommendations I5 (20I4) http://www.americanbar.org/content/dam/aba/administrative/professional_ responsibility/report_and_recommendations_of_aba_task_force.authcheckdam.pdf [https://perma.cc/U9MV-MVZ8] (noting that there is "a large-scale law faculty culture in the United States as well as sub-cultures particular to individual schools" and that "[c]ultures tend to be stable and not easily changed"). 
evaluated.59 To the extent faculty are resistant to accountability structures, allowing for self-evaluation, with some level of input from committee chairs, may be the way to balance concerns about heavy-handedness on the part of the administration with the need to institute some form of committee work contribution accountability.

Finally, while an evaluative process has the potential to improve committee workload performance by setting norms and expectations, evaluations of committee work contributions may have a limited impact if a dean is not willing to use the evaluations to reward outstanding citizens ${ }^{60}$ and to develop a plan of improvement for those who are not meeting their service obligations. For some deans, a willingness to engage in meaningful service work evaluation may hinge upon whether faculty members really want the dean to reward outstanding service and discipline those who repeatedly refuse to contribute to the collective endeavor. For others, it may rest upon different calculations. For example, is a dean willing to address in a constructive manner substandard service performance, especially if the faculty member is an outstanding scholar or teacher? Thus, to some extent, whether a concrete assessment of committee work contributions effectuates change may be a function of both culture and leadership.

\section{Reward Outstanding Committee Work with a Release from Future Committee Work}

While service work theoretically is part of every faculty member's job description and thus theoretically compensated, reality does not match theory. As discussed earlier, the current system incentivizes scholarly productivity. Faculty members may lose their jobs for failure to publish and often get

59. To the extent the evaluation involves input from committee chairs or involves other forms of peer evaluation, faculties might benefit from training on how to give and receive feedback, given that many faculty members have had no formal training in what makes feedback effective, and even fewer have had training in how to receive feedback. For an excellent book on how to receive feedback, see Douglas Stone \& Sheila Heen, Thanks for the Feedback: The Science and ARt of Receiving FeEdBack Well (20I4). If peer evaluation is used, faculty education should also include education about the role unconscious biases may play in performance assessment. See, e.g., Rebecca D. Gill et al., Are fudicial Performance Evaluations Fair to Women and Minorities? A Cautionary Tale from Clark County, Nevada, 45 Law \& Soc'y Rev. 73I (2OII) (reporting study results that suggest "objective" judicial performance evaluation surveys may reflect unconscious gender and racial biases). A recent study of teaching evaluations found implicit bias based on gender on ostensibly objective characteristics such as "promptness." Colleen Flaherty, Bias Against Female Instructors, Inside Higher Educ. (Jan. iI, 20I6), https://www. insidehighered.com/news/20I6/oI/II/new-analysis-offers-more-evidence-against-studentevaluations-teaching? utm_source $=$ Inside + Higher + Ed\&utm_campaign $=63$ ed 73 e $22 \mathrm{C}-$ DNU20I6oiri\&utm_medium=email\&utm_term=o_Ifcbco442I-63ed 73 e22c-I 97373353 \#. Vp6oUGB6K 7 Q.facebook [https://perma.cc/NC2U-XXBW].

6o. The rational theory of motivation suggests that when rewards are attached to performance, to the extent one recognizes that an evaluation will help determine those rewards, individuals are motivated to "pursue goals endorsed by whoever determines the rewards and to omit behaviors that detract from obtaining those rewards." Stewart et al., supra note 54 , at 436 . 
salary increases and course releases for well-placed and prolific publication. ${ }^{6 r}$ Some schools also reward outstanding teaching, although generally not to the same extent as outstanding scholarship. Currently, at many law schools, no significant tangible reward or remuneration exists for outstanding service, ${ }^{62}$ nor is one penalized for poor or nonexistent service. In this section, we suggest deans change the paradigm. Instead of "rewarding" outstanding service work with additional service work, we propose that deans reward institutional committee worker bees by giving them less service work via committee work release time. ${ }^{63}$

Given tight budgets and other institutional and university structures, meaningful financial remuneration may not be a viable reward for outstanding institutional service. However, deans could reward those who take on the lion's share of committee work with more time for scholarship so that they can reap the institutional rewards that frequently hinge upon scholarly productivity. ${ }^{6}$ The traditional way to create time is to award course releases. Teaching in law schools involves not only the hours spent in the classroom, but prep time, keeping abreast of new case law, and working with individual students or groups of students during office hours. Faculty members who are given a reduced course load are able to increase the time devoted to scholarship. However, a course release may not be viable given curricular needs and in light

6I. Shelley M. Park, Research, Teaching and Service: Why Shouldn't Women's Work Count?, 67 J. Higher EDUC. 46, 48 (I996) (noting the rewards in academia go to productive scholars, not those who perform institutional service). See also Benjamin Baez, Race-Related Service and Faculty of Color: Conceptualizing Critical Agency in Academe, 39 Higher Educ. 363,365 (200o) (noting that service is expected but not valued and, in fact, the promotion and tenure processes punish faculty members who do so much service that it hinders their publishing and teaching effectiveness); Silverman, supra note 32 , at $366-67$ (describing some of the external and internal rewards available to productive scholars and noting that this reward structure often promotes scholarship over teaching).

62. Some exceptions to this general rule exist. For example, Albany Law School grants a Faculty Excellence in Service award annually at graduation, an award accompanied by a small financial remuneration.

63. Deans could consider other rewards such as financial remuneration, or even creative rewards such as prime parking spots. However, those rewards fail to address the equity issues created by the time differentials required of those asked to perform significant institutional service. We note that service encompasses a wide range of categories, including (a) law school and university committee work and faculty governance service; (b) service to students; (c) law school or university project development and management; (d) administrative service as deans and program directors; (e) community service and outreach; and (f) professional service and leadership. See Clausen, supra note 8, at 238 . While administrative, community, and professional service are all valuable, that service work can have career-enhancing effects. On the other hand, internal institutional service work goes largely unrewarded, and can actually have a detrimental impact on one's career. See Guarino \& Borden, supra note 3. Thus, to remedy some of the inequities discussed throughout the article, we suggest an assessment structure that focuses on faculty committee service and rewarding extraordinary service with the luxury of time.

64. See supra note 27 (discussing rewards that accompany scholarly productivity). 
of the current and anticipated reduction in full-time faculty discussed earlier. ${ }^{65}$ Moreover, and in some situations, if one has been assigned a heavy committee burden that involves numerous tasks and requires significant attention, a course release may not provide the blocks of time that facilitate scholarship.

Thus we suggest a low-cost reward for extraordinary service: committee release time. ${ }^{66} \mathrm{~A}$ reward structure for outstanding service work, such as a year with no committee assignments, potentially could motivate some faculty members who do a moderate amount of work to more fully engage in service work, and it may help those who do the lion's share of the work continue to stay engaged rather than withdraw from what they perceive to be an inequitable system. ${ }^{67}$

We acknowledge that committee work release presents deans with a dilemma: If they relieve their best workers of committee work, will the work get done? That is the issue that underlies the common problem that the "reward for committee work well done is more committee work." Deans go to the people they know will get the work done because of the potential consequences of assigning the work to those who don't do it. We believe that institutions, and deans, should not sweep under the carpet the ethical issues raised by a system that places largely unrewarded service work burdens upon some so that others have more free time to engage in the scholarly work that garners tangible benefits both inside and outside a given institution. As we discussed in section II, supra, rewarding prolific scholars with more time for scholarship, while "rewarding" strong committee workers with more committee work and thus less time for scholarship, creates real-world inequities. ${ }^{68}$ Ignoring the unfairness of the current structure is particularly problematic when that model raises gender and racial equity issues. ${ }^{69}$

65. See supra Part I (discussing reduction in full-time faculty members).

66. In recognition of years of extraordinary service work, one of us was given a year with no law school committee assignments. That free time enabled her to write two articles and a book chapter-a level of scholarly productivity that was impossible when she was chairing two significant law school committees and a national professional organization committee.

67. See supra text accompanying note 39 (discussing the sucker effect).

68. See supra Part IIA.

69. Gender inequity in service workloads has been documented. See, e.g., Misra et al., supra note 33 , at 24 (finding female associate undergraduate professors spent approximately 4.5 more hours per week on institutional service than their male counterparts); Nancy Levit, Keeping Feminism in Its Place: Sex Segregation and the Domestication of Female Academics, 49 Kan. L. Rev. 775. 784-9o (200I) (discussing observational and anecdotal information about disparate service workloads among male and female law faculty); Guarino \& Borden, supra note 3 (finding that women faculty members spend substantially more time on internal service work than their male counterparts and thus have less time available to engage in work that reaps more substantial tangible rewards). So, too, racial inequities in committee service workloads are a real problem. See, e.g., Baez, supra note 6r, at 366-67 (2000) (discussing studies demonstrating heavy institutional service demands placed upon faculty of color). Intersectionality issues of race and gender result in even greater service workload inequities. Laura E. Hirshfield \& Tiffany D. Joseph, "We Need a Woman, We Need a Black Woman": Gender, Race and Identity Taxation in the Academy, 24 Gender \& Educ. 213 (2012) (discussing studies of service overloads on 
While this article recommends potential rewards for extraordinary contributions, we would be remiss if we did not suggest that deans consider penalties for a pattern of substandard service work contributions. In today's world, deans cannot ignore the fact that some faculty members do not engage in institutional committee work, nor can they continue to count on the worker bees to get all the work done. Thus, the idea of committee work rewards goes hand in hand with creating committee work participation accountability structures, such as institutionalized committee work evaluations. These evaluations create behavioral norms and hopefully voluntarily enhance faculty committee work participation. However, they also provide deans with documentation that enables them to reward outstanding citizens and confront those who consistently fail to carry their fair share of the workload.

\section{Conclusion}

Evidence suggests there will be an increase in faculty committee work demands and fewer people available to do that work. In an era of enhanced accreditation burdens and market force restructuring ${ }^{70}$ that require more committee work, faculties and deans must address committee workload inequities if they wish to maintain a robust system of faculty self-governance and avoid institutional stagnation. This article presents ideas that serve as a starting point for exploring how schools might preserve a robust system of faculty governance while also addressing the inequitable workload allocations and reward systems that exist at many institutions.

women, people of color, and particularly women of color). It is beyond the scope of this article to discuss the gender and racial inequities in service work allocations. While we hope that some proposals in this article lessen overall faculty committee workload disparities, we recognize that to fully counter gender and racial service workload inequities, additional issues must be confronted and addressed.

70. See supra Part I (discussing changes in legal education that likely will result in the need for additional institutional service). 


\section{Appendix A-Committee Work Contribution Rubric- Adapted from: SMET Group Work Rubric*}

\begin{tabular}{|c|c|c|c|c|c|}
\hline $\begin{array}{l}\text { Committee } \\
\text { Work } \\
\text { Assessment }\end{array}$ & $\begin{array}{c}4 \\
\text { Excels }\end{array}$ & $\begin{array}{c}3 \\
\text { Meets } \\
\text { expectations }\end{array}$ & $\begin{array}{c}2 \\
\text { Does not fully } \\
\text { meet } \\
\text { expectations }\end{array}$ & $\begin{array}{c}\text { I } \\
\text { Does not meet } \\
\text { minimum } \\
\text { expectations }\end{array}$ & Score \\
\hline $\begin{array}{l}\text { Participation/ } \\
\text { constructive } \\
\text { work }\end{array}$ & $\begin{array}{l}\text { Frequently } \\
\text { offers ideas } \\
\text { that move } \\
\text { the commit- } \\
\text { tee's work } \\
\text { forward; } \\
\text { extremely } \\
\text { good at } \\
\text { identifying } \\
\text { problems } \\
\text { or complex } \\
\text { issues and } \\
\text { proposing } \\
\text { workable } \\
\text { solutions }\end{array}$ & $\begin{array}{l}\text { Sometimes } \\
\text { offers ideas } \\
\text { that move } \\
\text { the commit- } \\
\text { tee's work } \\
\text { forward; } \\
\text { good at } \\
\text { identifying } \\
\text { problems } \\
\text { or complex } \\
\text { issues and } \\
\text { sometimes } \\
\text { proposes } \\
\text { potential } \\
\text { workable } \\
\text { solutions }\end{array}$ & $\begin{array}{l}\text { Seldom offers } \\
\text { ideas that } \\
\text { move the } \\
\text { committee's } \\
\text { work forward; } \\
\text { rarely } \\
\text { identifies } \\
\text { problem } \\
\text { spots, } \\
\text { complexities } \\
\text { or proposes } \\
\text { workable } \\
\text { solutions }\end{array}$ & $\begin{array}{l}\text { Ideas and } \\
\text { attitude tend } \\
\text { to be } \\
\text { disruptive } \\
\text { rather than } \\
\text { helpful }\end{array}$ & \\
\hline $\begin{array}{l}\text { Listening and } \\
\text { working } \\
\text { with others }\end{array}$ & $\begin{array}{l}\text { Works } \\
\text { extremely } \\
\text { well with } \\
\text { others; } \\
\text { actively } \\
\text { listens; } \\
\text { encourages } \\
\text { all to } \\
\text { participate }\end{array}$ & $\begin{array}{l}\text { Generally } \\
\text { works } \\
\text { well with } \\
\text { others; } \\
\text { sometimes } \\
\text { encourages } \\
\text { others to } \\
\text { express their } \\
\text { views }\end{array}$ & $\begin{array}{l}\text { Struggles to } \\
\text { work well in a } \\
\text { group setting; } \\
\text { struggles } \\
\text { with listening } \\
\text { respectfully to } \\
\text { others' ideas } \\
\text { and allowing } \\
\text { others an op- } \\
\text { portunity to } \\
\text { express their } \\
\text { ideas }\end{array}$ & $\begin{array}{l}\text { Does not } \\
\text { work well } \\
\text { with others, } \\
\text { fails to listen } \\
\text { to others; tries } \\
\text { to dominate } \\
\text { the discussion }\end{array}$ & \\
\hline $\begin{array}{l}\text { Team role } \\
\text { fulfillment }\end{array}$ & \begin{tabular}{|l} 
Participates \\
in all \\
meetings, \\
assumes \\
leadership \\
role as \\
necessary
\end{tabular} & $\begin{array}{l}\text { Participates } \\
\text { in most } \\
\text { meetings; } \\
\text { provides } \\
\text { leadership } \\
\text { when asked }\end{array}$ & $\begin{array}{l}\text { Participates in } \\
\text { some } \\
\text { meetings; } \\
\text { seldom takes } \\
\text { leadership } \\
\text { role }\end{array}$ & $\begin{array}{l}\text { Participates } \\
\text { in few or no } \\
\text { meetings; } \\
\text { provides no } \\
\text { leadership }\end{array}$ & \\
\hline
\end{tabular}




\begin{tabular}{|c|c|c|c|c|c|}
\hline $\begin{array}{l}\text { Committee } \\
\text { Work } \\
\text { Assessment }\end{array}$ & $\begin{array}{c}4 \\
\text { Excels }\end{array}$ & $\begin{array}{c}3 \\
\text { Meets } \\
\text { expectations }\end{array}$ & $\begin{array}{c}2 \\
\text { Does not fully } \\
\text { meet } \\
\text { expectations }\end{array}$ & $\begin{array}{c}\text { I } \\
\text { Does not meet } \\
\text { minimum } \\
\text { expectations }\end{array}$ & Score \\
\hline $\begin{array}{l}\text { Communication } \\
\text { /information } \\
\text { sharing }\end{array}$ & $\begin{array}{l}\text { Provides } \\
\text { effective } \\
\text { feedback to } \\
\text { other } \\
\text { members; } \\
\text { relays a } \\
\text { great deal } \\
\text { of useful } \\
\text { information } \\
\text { when asked } \\
\text { to gather } \\
\text { information } \\
\text { as part of } \\
\text { committee's } \\
\text { task }\end{array}$ & $\begin{array}{l}\text { Provides } \\
\text { some useful } \\
\text { effective } \\
\text { feedback to } \\
\text { others; } \\
\text { relays } \\
\text { some basic } \\
\text { information } \\
\text { when asked } \\
\text { to gather } \\
\text { information } \\
\text { as part of } \\
\text { committee's } \\
\text { task }\end{array}$ & $\begin{array}{l}\text { Provides } \\
\text { little useful } \\
\text { feedback to } \\
\text { others; relays } \\
\text { very little } \\
\text { useful } \\
\text { information } \\
\text { when asked to } \\
\text { gather } \\
\text { information } \\
\text { as part of } \\
\text { committee's } \\
\text { task }\end{array}$ & $\begin{array}{l}\text { Provides } \\
\text { no useful } \\
\text { feedback } \\
\text { to others; } \\
\text { when asked } \\
\text { to gather } \\
\text { information, } \\
\text { does not do } \\
\text { so or relays } \\
\text { information } \\
\text { that is not } \\
\text { useful to the } \\
\text { committee's } \\
\text { work }\end{array}$ & \\
\hline Workload & $\begin{array}{l}\text { Always will- } \\
\text { ing to help } \\
\text { and do more } \\
\text { work; does } \\
\text { substantially } \\
\text { more than } \\
\text { others; often } \\
\text { volunteers } \\
\text { for tasks; } \\
\text { often helps } \\
\text { others with } \\
\text { their work- } \\
\text { highly } \\
\text { productive }\end{array}$ & $\begin{array}{l}\text { Cooperative } \\
\text { and willing } \\
\text { to do his/her } \\
\text { fair share; } \\
\text { occasionally } \\
\text { volunteers } \\
\text { for tasks; } \\
\text { occasionally } \\
\text { helps } \\
\text { others; does } \\
\text { his/her fair } \\
\text { share of the } \\
\text { work }\end{array}$ & $\begin{array}{l}\text { Sometimes } \\
\text { does } \\
\text { committee } \\
\text { work; rarely if } \\
\text { ever } \\
\text { volunteers; } \\
\text { could do } \\
\text { more of the } \\
\text { committee's } \\
\text { work }\end{array}$ & $\begin{array}{l}\text { Rarely does } \\
\text { any work; } \\
\text { never } \\
\text { volunteers; } \\
\text { avoids taking } \\
\text { on any work }\end{array}$ & \\
\hline Work quality & $\begin{array}{l}\text { Work is } \\
\text { complete, } \\
\text { well- } \\
\text { organized, } \\
\text { error-free, } \\
\text { submitted } \\
\text { on time or } \\
\text { early; } \\
\text { committee } \\
\text { can use the } \\
\text { work as } \\
\text { drafted }\end{array}$ & $\begin{array}{l}\text { Work is } \\
\text { generally } \\
\text { complete, } \\
\text { meets the } \\
\text { requirements } \\
\text { of the task, } \\
\text { and is mostly } \\
\text { done on } \\
\text { time; } \\
\text { committee } \\
\text { can use work } \\
\text { as drafted } \\
\text { with minor } \\
\text { revisions }\end{array}$ & $\begin{array}{l}\text { Work tends to } \\
\text { be disorderly, } \\
\text { incomplete, } \\
\text { inaccurate, } \\
\text { and often } \\
\text { late; } \\
\text { committee } \\
\text { must do } \\
\text { significant } \\
\text { rewrites or } \\
\text { edits before } \\
\text { being able to } \\
\text { use work }\end{array}$ & $\begin{array}{l}\text { Work is } \\
\text { sloppy, } \\
\text { incomplete, } \\
\text { has excessive } \\
\text { errors and is } \\
\text { mostly late or } \\
\text { not turned in } \\
\text { at all; } \\
\text { committee } \\
\text { often cannot } \\
\text { use the work } \\
\text { and must } \\
\text { assign to } \\
\text { someone else }\end{array}$ & \\
\hline
\end{tabular}


What is the single most valuable contribution you made to your committee? What is the single most important thing you could do to more effectively help your committee?

*The original author of this rubric cannot be determined. SMET refers to Science, Math,

Engineering, and Technology. The rubric is available at https://perma.cc/ $\mathrm{XSN}_{4}$-GHVF. 